\title{
IDENTIFICATION OF SOME VOLATILE COMPOUNDS EXTRACTED FROM CERTAIN MEDICAL PLANTS
}

\author{
Moussa, M.M. ${ }^{1}$, Massoud, Mona, I. $^{2}$ \& Zeitoun, M.A. ${ }^{3}$ \\ ${ }^{1}$ Food Science \& Technology Dept. Fac. of Agric, Alex . Univ. Alexandria, Egypt \\ ${ }^{2}$ Sugar Crops Res. Inst. El Sabahia, Alexandria, Egypt \\ ${ }^{3}$ Food Science Dept., Fac. of Agric. (Saba Bacha), Alex. Univ., Alexandrie, Egypt
}

\begin{abstract}
Stevia rebaudiana Bertoni, licorice (Glycyrrhiza glabra L.), carob (Ceratonia siliqua L.) and chicory (Chichorum intybus L.) are considered medicinal plants with many traditional uses such as sweetener plants. The volatile oils of these plants were isolated by steam distillation process. Identification of volatile compounds present in these volatile oils was assayed using Gas chromatography - Mass spectrometry (GC-MS). The volatile oil contents were about $0.24,0.12,0.08$, and $0.27 \%$ of dried stevia leaves, licorice roots, carob pulp and chicory roots, respectively. The nerolidol, benzyl, $\delta$.cadinene and caryophyllene were the major volatile compounds of stevia leaves, while methyl chavicol and benzaldehyde were the main ones of licorice. Carob pulp contained the hexanoic acid as the major component. The main constituents were benzoic acid, verapamil and verbenone in chicory roots. The volatile oils are very important for their activity as an anti-inflammatory drug, and also could be used as an anti-bacterial and flavouring agents in the field of food industry.
\end{abstract}

Keywords : volatile compounds, medical plants, sweetener plants, anti-inflammatory, antibacterial, flavouring agents

\section{INTRODUCTION}

Volatile oils, also called essential oils (EOs) are aromatic oily liquids obtained from plant materials by expression, fermentation, or extraction, but the method of steam distillation is most commonly used for commercial production of EOs (Van de Braak \& Leijten, 1999). The greatest use of EOs in food is as flavourings and pharmaceuticals (for their functional properties). Some EOs or their components have been shown to exhibit antimicrobial (Nychas, 1995), insecticidal (Karpouhtsis et al., 1998), antitoxigenic (Juglal et al., 2002), antiparasitic (Pessoa et al., 2002), antiviral and antimycotic (Mari et al., 2003) properties.

Stevia rebaudiana Bertoni is an herbaceous perennial native to the highlands of Paraguay. It is especially known for the sweetening principles contained in the leaves, which have attracted the attention of both researchers and industrial producers because of their potential dietetic, alimentary and pharmaceutical interest (Jeppesen et al., 2000).

The leaves of stevia contain a complex mixture of labdone diterpenes, triterpenes, stigmasterol, tannins, volatile oils and eight sweet diterpene glycosides (Pasquel et al., 2000). The dry herb yielded $0.12-0.16 \%$ essential oil. Chamazulene that isolated from the essential oil may be considered as a particular source of anti-inflammatory, antimitotic and antiasthmatic compound (Roman et al., 1990). The plant has also been used to treat different diseases such as diabetes, hypoglycemia, candidiasis, high blood pressure, skin abrasions and inhibiting growth and reproduction of bacteria-like plaque (Geuns, 2003).

Licorice (Glycyrrhiza glabra L.) is a flavourful herb that has been widely used in foods as a natural sweetener as well as a flavouring agent and can be added to foodstuffs in small quantities, with possible limitation of an active principle in the final product (Jiang et al., 2004). In USA, licorice is listed as known medicines in ancient history. It is a wonderful tonic herb for winter. This herb has long been valued as demulcent (soothing and coating agent) illnesses and immune, digestive tract, respiratory tract, and adrenal gland support (Luper, 1999). Furthermore, it has been used for bronchial catarrh, bronchitis, chronic 
gastritis, peptic ulcer, colic and primary adrenocortical insufficiency (Tamir et al., 2001). Also licorice root showed an antibacterial effect, it is used as an anti-inflammatory drug (Tanaka et al., 2001) and as an antiallergic and antiasthmatic agent (Bielenberg, 2001).

There are many components in licorice but the most active one is glycyrrhizin that gives licorice its sweet taste. Other components are saponins (triterpenoid glycosides), flavonoids (including liquicritigetol) and isoflavonoids, bitter principle (glycyrmarin), volatile oil, chalcones, coumarins, amino acids, amines (choline, betaine, aspargine), oestrogenic substances (including beta-sitosterol), starch, sugars (glucose and sucrose), tannis, gums and wax (Michael, 2003).

Carob (Ceratonia siliqua L.) is a fruit from a dark evergreen tree that belongs to the family leguminoseae. Carob pods are nutritious due to their high sugar content, (Camacho et al., 1996). The decoction of the pulp is antidiarrheal, gently helping to cleanse and relieve irritation within the gut (Aksit et al., 1998). Other applications of pulps are in pharmaceutical products, sugar extraction (Marakis, 1992) and ethanol production (Roukas, 1994). Flavour and aroma are fundamental attributes of these products.

Chicory (Cichorium intybus L.) is a potential source of fructose for use as a sweetener in food, medicinal and energetic potential (Piet, 1996). Chicory root is known to be laxative, stomachic and diuretic. Its decoction is used as a tonic in fevers and for the treatment of jaundice, enlargement of spleen, gout and rheumatism (Hazra et al., 2002). The same author added that, chicory contains the active component inulin. Herbalists recommend using this herb as an anti-inflammatory, choleretic, digestive tonic, laxative, mild diuretic and stomachic for anemia, liver disorders, kidney and gallstones, and urinary tract inflammations. It has been found also to significantly lower cholesterol and blood sugar levels. The sequiterpene lactones found in roasted root kill bacteria. Internally, it can be used for diabetes, dry coughs, abscesses, childbirth (second stage of labor), and abortion (tubers); bronchial infections with thick phlegm, chest pain and tightness; dry constipation, lung and breast tumor.
Therefore, the objectives of the present study were to identify, the volatile compounds in the aforementioned medical herbs.

\section{MATERIALS AND METHODS}

\section{Materials}

Stevia rebaudiana Bertoni leaves were obtained from El-Sabahia Station, Agricultural Research Center, Alexandria, Egypt.

Chicory (Chichorum intybus L.) was obtained from Agric. Res. Center Farm at Giza, Cairo, Egypt.

Licorice (Glycyrrhiza glabra L.) and carob (Ceratonia Siliqua L.) were obtained from local market in Alexandria, Egypt.

All plants used in the present study were dried in an air oven at $45 \pm 2^{\circ} \mathrm{C}$ until reaching stable moisture content, then grinded and passed through 60-mesh sieve. Different sample powders were kept in polyethylene bags and stored at $4^{\circ} \mathrm{C}$ until use.

\section{Methods}

Steam distillation process: One hundred grams from each of the dried plant materials were added to 1 liter of distilled water and subjected to steam distillation procedure for 2 hours. After distillation, the volatile oils were extracted from the condensed steam by hexane; the extract was concentrated in a rotary evaporator at room temperature. The extracted volatile oils were stored in airtight dark containers and kept in a refrigerator at 4 ${ }^{\circ} \mathrm{C}$ until analysis (Martelli et al., 1985).

Gas chromatography - Mass spectrometry (GC-MS): Identification and quantification of volatile compounds present in volatile oils were performed on the concentrated extracts of samples using a GC Hewlett Packard 5890 series coupled with a MS-HP 5989B. One $\mu \mathrm{l}$ of volatile oil extract was injected into a glass capillary column PH 5; MS (5\% diphenyl 95\% dimethyl polysiloxane) (30 nm, $0.25 \mathrm{~mm}$ i.d., film thickness 0.25 um) using a splitless mode injector. The column inlet pressure was 5.3 Psi and helium was used as a carrier gas $(0.8 \mathrm{ml} / \mathrm{min})$. The oven temperature was programmed as follows: the initial temperature $100^{\circ} \mathrm{C}$ for 6 min., then from $100^{\circ} \mathrm{C}$ to $220^{\circ} \mathrm{C}$ at $10^{\circ} \mathrm{C} / \mathrm{min}$ for $22 \mathrm{~min}$., and finally remaining at $220^{\circ} \mathrm{C}$ for $40.5 \mathrm{~min}$. The MS parameters were as follows, temperature of ion source, $125^{\circ} \mathrm{C}$, mass interval $50-550 \mathrm{~m} / \mathrm{e}$ ionization energy, and 
70ev (Cantalejo, 1997).The volatile compound was identified by library reference spectra (with a quality exceeding 85\%) and quantified by integration of the mass spectrometer total ionization current by a real time computer .The concentration of volatile compounds were calculated by two methods, the first as percent of total area and the second as weight percent of the volatile oil.

\section{RESULTS AND DISCUSSION}

The volatile compounds of volatile oils obtained by steam distillation from Egyptian dried stevia leaves, dried licorice roots, dried carob pulp and dried chicory roots were analyzed using GC-MS. Chromatograms of volatile compounds of volatile oil samples are shown in Fig (1a, b, c, and d). Tables (1, 2, 3 and 4 ) show the identified volatile compounds: and their concentrations of the volatile oils. The yields of the volatile compounds were about $0.241,0.116,0.082$ and $0.270 \%$ of the dried stevia leaves, licorice roots, carob pulp and chicory roots, respectively. Twenty-two volatile compounds were identified in stevia leaves extract. Among these compounds, nerolidol, benzyl alcohol, $\delta$-cadinene, caryophyllene, caryophyllene oxide and $\alpha$-humulene were the major components which represented $17.1,13.8,8.9,6.9,6.5$ and $5.2 \%$, respectively (Table 1). The obtained results are in agreement with Martelli et al. (1985) who reported that the major components in the essential oil of Brazil stevia were the sesquiterpenes caryophyllene oxide and nerolidol, where the monoterpenes were linalool, terpinen-4ol and terpineol. In contrast Tsanava et al. (1991) reported that caryophyllene oxide and spathulenol were the dominant, since they represent about $43 \%$ of stevia essential oil. These variances are mainly due to the different climatic and geographical conditions in which stevia plants are grown (Kinghorn, 2002 \& Burt, 2004). The nerolidol, the dominant volatile compound of stevia, has strong antimicrobial activity and can be used for treatment or inhibition of microbial infections (Pauli \& Schilcher, 2004). Also, benzyl alcohol is commonly used as an antibacterial agent in a variety of pharmaceutical formulations (Dasgupta \& Humphrey ,1998). From the above results and those mentioned in the literature, it could be noticed that stevia volatile oil extract contains rich proportion of aromatic aldehyde, monoterpenes and sesqui-terpenes, thus it can be used as a flavour enhancer in foods and food products (Buckenhuskers \& Omran, 1997; Geuns, 2003).

Table (2) shows the volatile compounds of the volatile oil extracted from dried licorice powder. Licorice volatile compounds were found to contain nine compounds. Methyl chavicol (41.80\%), linalool (16.87\%), benzaldehyde (15.88\%), 1, 8 cincole $(7.47 \%)$, and furfuryl alcohol $(6.99 \%)$ were the predominant components followed by hexanol $(1.70 \%), \alpha$-terpineol $(1.50 \%)$ and propionic acid $(1.23 \%)$. These data agreed well with those of Tucker and Maciarello (1999) who found that the main constituents of volatile oil of licorice verbena leaf were methyl chavicol $(56.46 \pm 4.29 \%)$ and 1,8 cincole $(12.62 \pm$ $4.26 \%$ ). On the other hand, Kameoka \& Nakai (1987) identified that more than 80 components of licorice including anethole, benzaldehyde, butyrolactone, cumic alcohol, hexan-ol, furfuryl alcohol, indol, linalool, propionic acid, and $\alpha$ - terpineol. Katayoun et al. (2003) suggested the possibility of using a licorice extract as an effective natural antioxidant. Methyl chavicol (estragol), is an important constituent of many essential oils with widespread applications in folk medicine and aromatherapy and known to have potent local anesthetic activity (Cardoso et at., 2004). Licorice root is used as a natural source of food flavouring, it is a wonderful medicine, real good seller in capsules and it has been used for bronchial catarrh, bronchitis, chronic gastritis, peptic ulcer, colic and primary adrenocortical insufficiency (Jiang et al., 2004)

Thirty volatile compounds of carob pulp were identified (Table 3). The major compounds were hexanoic acid $(18.16 \%)$, 3-ethyl5-methyl pyridine (10.69\%), 2-octen-2one $(6.27 \%)$ and octanoic acid (5.32\%). The other identified volatile compounds occurred at concentrations of $5 \%$. Macleod \& Forcen (1992) found that, seven aliphatic acids represented an extraordinarily high level (77.5\%) of the volatile components were isolated from carob beans oil. They mentioned that methyl propanoic acid (45\%), hexanoic acid (19\%) and 2-methyl butanoic acid (8\%) are the major acids in volatile components of carob pulp. 


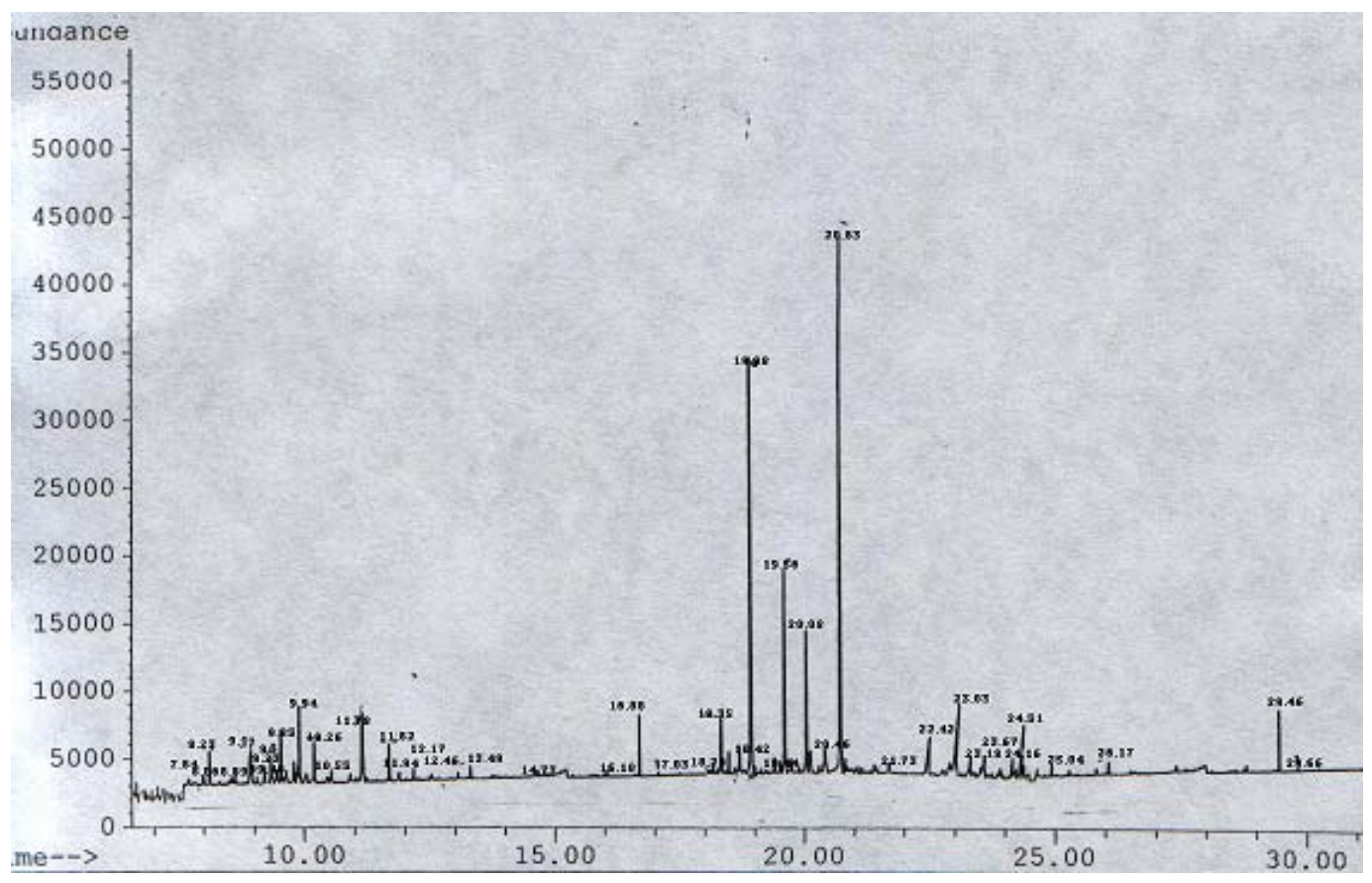

Fig (1.a): GC-MS Chromatogram of volatile compounds of stevia leaves

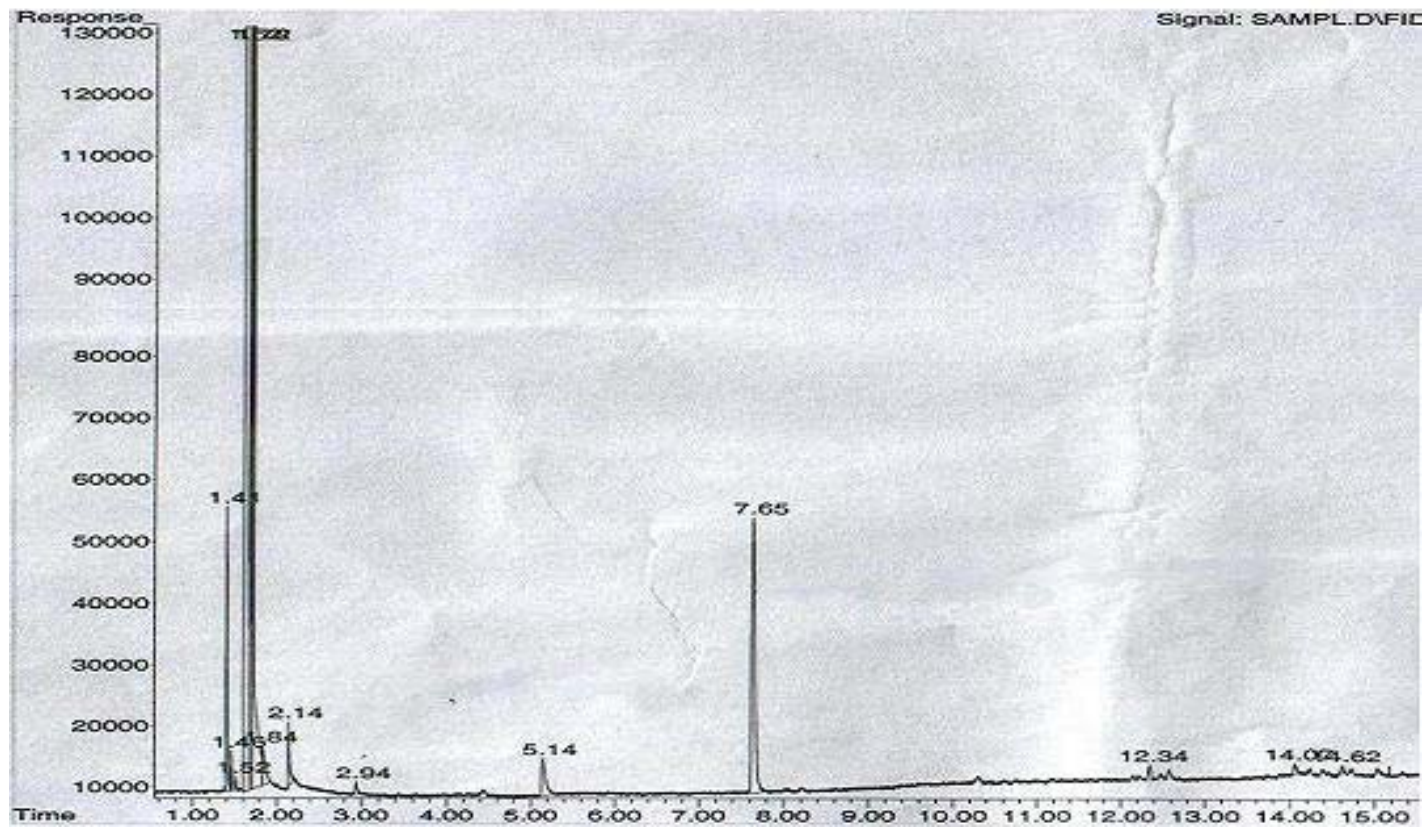

Fig (1.b): GC-MS Chromatogram of volatile compounds of licorice roots 


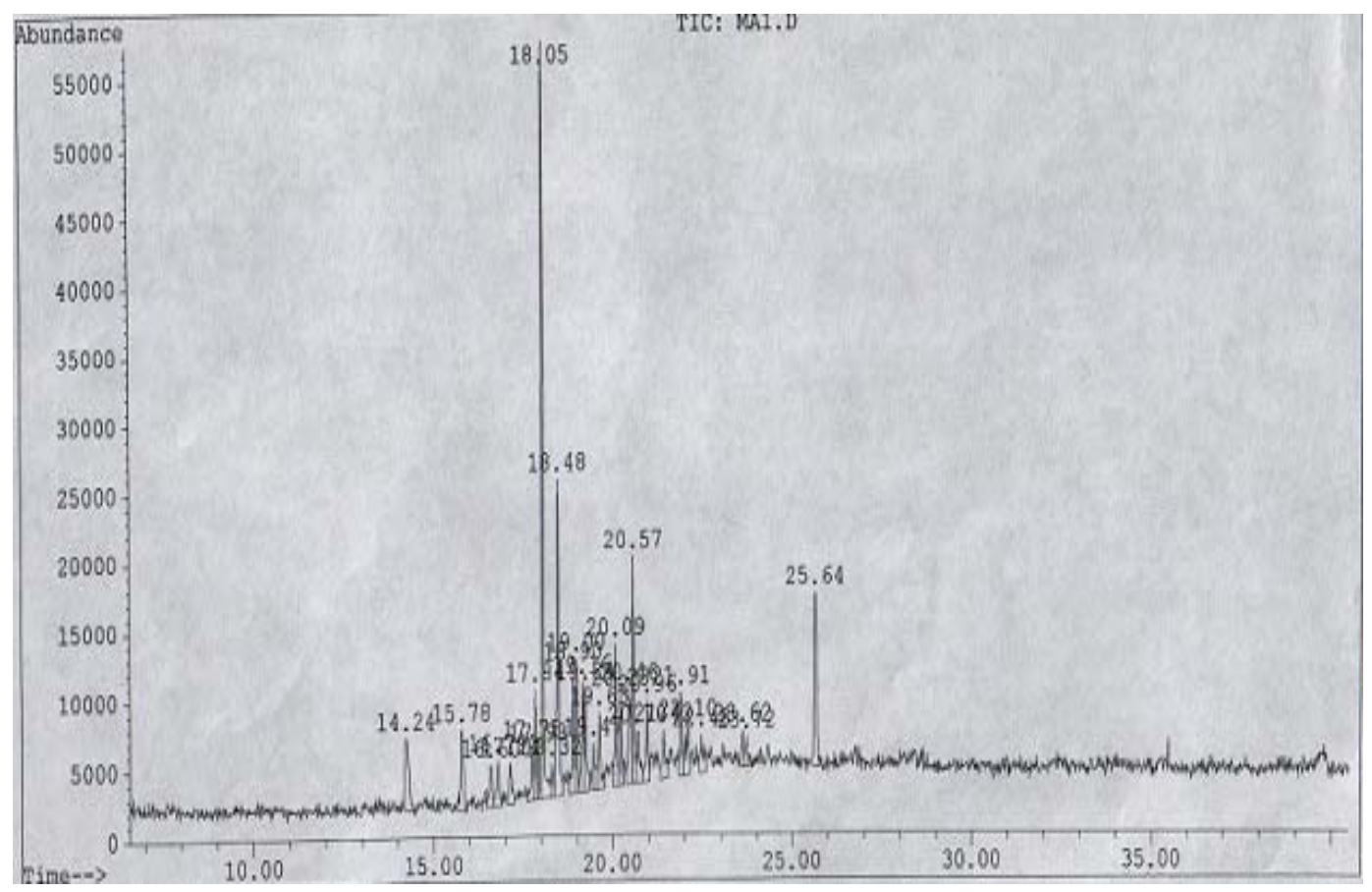

Fig (1.c): GC-MS Chromatogram of volatile compounds of carob pulp

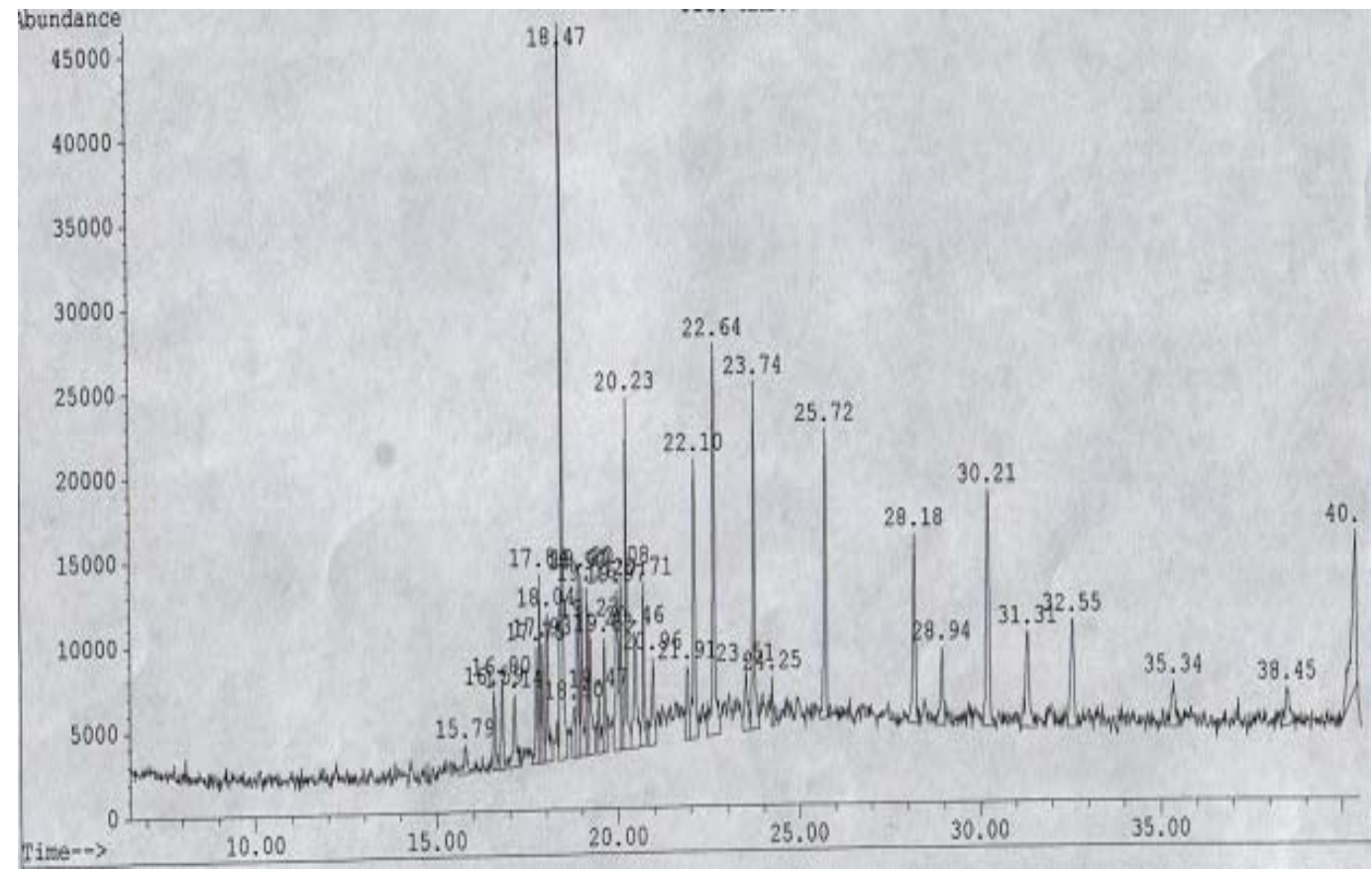

Fig (1.d): GC-MS Chromatogram of volatile compounds of chicory roots 
Table 1: Volatile compounds identified by GC-MS in Stevia rebaudiana

\begin{tabular}{|c|c|c|c|}
\hline \multirow{2}{*}{ Compounds } & \multirow{2}{*}{$\begin{array}{l}\text { Retention time } \\
\text { (min) }\end{array}$} & \multicolumn{2}{|c|}{ Concentration as } \\
\hline & & Area\% & $\mathrm{mg} / 100 \mathrm{~g}$ \\
\hline$\alpha$ - Pinene & 7.84 & 0.9 & 2.16 \\
\hline n - Hexanal & 8.06 & 1.1 & 2.64 \\
\hline Limonene & 8.23 & 3.4 & 8.19 \\
\hline 1,8 Cincole & 9.17 & 2.2 & 5.30 \\
\hline$\gamma$ - Terpinene & 9.23 & 0.8 & 1.93 \\
\hline $\mathrm{P}$ - Cymene & 9.46 & 1.9 & 4.57 \\
\hline 3 - Octanol & 9.73 & 0.9 & 2.17 \\
\hline $1-$ Octen -3 ol & 9.85 & 4.3 & 10.36 \\
\hline Linolool & 9.94 & 3.9 & 9.39 \\
\hline Comphor & 10.55 & 2.7 & 6.51 \\
\hline Caryophyllene & 11.18 & 6.9 & 16.63 \\
\hline$\alpha$-Humulene & 11.82 & 5.2 & 12.53 \\
\hline Sesquilerpene ketones & 16.88 & 4.1 & 9.88 \\
\hline$\alpha-$ Terpinol & 18.35 & 3.3 & 7.95 \\
\hline Anethol & 18.42 & 2.0 & 4.82 \\
\hline Benzyl alcohol & 19.08 & 13.8 & 33.25 \\
\hline$\delta$ - Cadinene & 19.56 & 8.9 & 21.44 \\
\hline Caryophyllene oxide & 20.08 & 6.5 & 15.67 \\
\hline Nerolidol & 20.83 & 17.1 & 41.21 \\
\hline Spothulenol & 22.42 & 2.9 & 6.98 \\
\hline Eugenol & 23.67 & 1.3 & 3.13 \\
\hline Carvacnol & 24.51 & 2.9 & 6.98 \\
\hline 7 unknown & $\begin{array}{c}9.53,12.46,13.44,14.75 \\
20.46,21.71,26.17\end{array}$ & 3.0 & 7.20 \\
\hline
\end{tabular}

Table 2: Volatile compounds identified by GC-MS in licorice

\begin{tabular}{lccc}
\hline \multirow{2}{*}{ Compounds } & Retention time & \multicolumn{2}{c}{ Concentration as } \\
\cline { 3 - 4 } & $(\mathbf{m i n})$ & Area \% & $\mathbf{m g} / \mathbf{1 0 0 g}$ \\
\hline 1,8 cincole & 2.14 & 7.47 & 12.84 \\
Hexanol & 1.52 & 1.70 & 1.97 \\
Methyl chavicol & 1.70 & 41.80 & 48.48 \\
Linalool & 1.41 & 16.87 & 19.56 \\
Propionic acid & 2.94 & 1.23 & 1.43 \\
Furfuryl alcohol & 5.14 & 6.99 & 8.11 \\
Benzaldehyde & 7.65 & 15.88 & 18.42 \\
$\alpha-$ Terpineol & 12.34 & 1.50 & 1.74 \\
Butyrolactone & 14.07 & 0.91 & 1.05 \\
3 unknown & $1.46,1.84,14.62$ & 5.65 & 6.54 \\
\hline
\end{tabular}


Table 3: Volatile Compounds identified by GC-MS in carob

\begin{tabular}{|c|c|c|c|}
\hline \multirow{2}{*}{ Compounds } & \multirow{2}{*}{$\begin{array}{l}\text { Retention } \\
\text { time (min) }\end{array}$} & \multicolumn{2}{|c|}{ Concentration as } \\
\hline & & Area \% & $\mathrm{mg} / 100 \mathrm{~g}$ \\
\hline Isobutyric acid & 14.24 & 3.96 & 3.25 \\
\hline 2- Methyl pentanoic acid & 15.78 & 3.45 & 2.83 \\
\hline Caryophyllene & 16.60 & 1.67 & 1.36 \\
\hline Phenyl acetaldehyde & 16.80 & 1.71 & 1.40 \\
\hline 4 - Terpineol & 17.14 & 1.65 & 1.35 \\
\hline $\mathrm{p}$ - Vinyl guaiacol & 17.74 & 1.80 & 1.47 \\
\hline Methyl benzoate & 17.83 & 2.61 & 2.14 \\
\hline 2 - Phenyl ethyl & 17.92 & 1.14 & 0.93 \\
\hline Hexanoic acid & 18.04 & 18.16 & 14.89 \\
\hline Octadecane & 18.31 & 0.76 & 0.62 \\
\hline 3 Ethyl-5 methyl pyridine & 18.47 & 10.69 & 8.76 \\
\hline Benzoic acid & 18.90 & 3.47 & 2.85 \\
\hline 1 - butyl octyl benzene & 19.01 & 2.87 & 2.35 \\
\hline Acetophenone & 19.17 & 2.53 & 2.07 \\
\hline Methyl acetophenone & 19.24 & 2.96 & 2.43 \\
\hline Hexacosane & 19.47 & 1.75 & 1.44 \\
\hline 3 Phenyl dodecane & 19.63 & 2.45 & 2.0 \\
\hline Auraptene & 20.08 & 3.65 & 2.99 \\
\hline 1 butyl nonyl benzene & 20.22 & 2.23 & 1.82 \\
\hline Methyl cyclopentenotone & 20.45 & 3.68 & 3.02 \\
\hline Octanoic acid & 20.58 & 5.32 & 4.36 \\
\hline Pentadecane & 20.70 & 2.13 & 1.74 \\
\hline Ethyl cinnamete & 20.97 & 2.42 & 1.98 \\
\hline Trimethyl gallic acid & 21.42 & 2.18 & 1.79 \\
\hline Cumaldehyde & 21.92 & 2.18 & 1.79 \\
\hline Heneicosane & 22.09 & 2.28 & 1.87 \\
\hline Chavicol & 22.49 & 1.95 & 1.59 \\
\hline Methyl chavicol (cymene) & 23.61 & 0.97 & .79 \\
\hline 2 Methyl 2 ethyl propanoic acid & 23.72 & 1.08 & .89 \\
\hline 2 Octen -2one & 25.64 & 6.27 & 5.14 \\
\hline
\end{tabular}

Cantalejo (1997) reported that acids, alcohols and aldehydes represent $91.4 \%$ of the total identified compounds in raw carob pulp. Volatile components of carob pulp could be used in foods as flavouring agents.

Data presented in Table (4) show that 37 volatile compounds were found in chicory roots but 31 only were identified as shown in Fig.(1-d).The volatile compounds extracted contains benzoic acid (11.16\%) as a major constituent, followed by verapamil $(6.67 \%)$, verbenone, 2,4,dimethyl 3-hexanone and isoamyl salciylate.
Chicory roots contain relatively high amounts of 4 hydroxy phenylacetic, benzoic and 3,4 dihydroxycinnamic acids which contain 12 aromatic acids (Sannai et al.,1982). Baek \& Cadwallader (1998) studied the volatile profiles of roasted chicory root by gas chromatography / mass spectrometry/olfactometry. Many pyrazines and n-furfuryl pyrroles were identified for the first time in roasted chicory. 2 ethyl 3-5dimethylpyrazine 2,3-butanedione, 1-octen-3 one and 3-methylbutanol were the most intense aroma - active components found in roasted chicory. 
Table 4: Volatile Compounds identified by GC-MS in chicory roots

\begin{tabular}{|c|c|c|c|}
\hline \multirow{2}{*}{ Compounds } & \multirow{2}{*}{$\begin{array}{c}\text { Retention time } \\
\text { (min) }\end{array}$} & \multicolumn{2}{|c|}{ Concentration as } \\
\hline & & Area\% & $\mathrm{mg} / \mathbf{1 0 0 g}$ \\
\hline Benzyl benzote & 16.58 & 1.33 & 3.59 \\
\hline 4 - Terpineol & 16.80 & 1.27 & 3.43 \\
\hline Methyl benzoate & 17.85 & 2.12 & 5.72 \\
\hline 2 Phenyl hexane & 17.92 & 1.36 & 3.67 \\
\hline 1 - Phenyl 2 ptapanone & 18.04 & 2.27 & 6.13 \\
\hline Benzoic acid & 18.47 & 11.16 & 30.13 \\
\hline Sesquibenihiol & 18.79 & 1.07 & 2.89 \\
\hline 1 - Pentyl heptyl benzene & 18.90 & 2.13 & 5.75 \\
\hline 1-Butanedione (butyl octyl benzene) & 19.01 & 2.38 & 6.43 \\
\hline Acetophenone & 19.17 & 1.71 & 4.62 \\
\hline 1 - Propylnonyl benzene & 19.24 & 2.06 & 5.56 \\
\hline Ethyl 5 - methyl pyrazine & 19.63 & 1.48 & 3.99 \\
\hline 5 - (Trimethylsilyl) methyl 2 phenyl & 19.97 & 2.98 & 8.05 \\
\hline Dimethoxy benzaldehyde & 20.08 & 2.28 & 6.15 \\
\hline 2,4, Dioctyl phenol & 20.24 & 4.06 & 10.96 \\
\hline 1,3,3 Trimethylindole benzene & 20.47 & 2.87 & 7.74 \\
\hline Eicosane & 20.70 & 1.99 & 5.37 \\
\hline Auraptene & 20.95 & 1.64 & 4.42 \\
\hline Cinnamyl cinnamate & 21.92 & 1.27 & 3.43 \\
\hline Benzyl cinnamate & 22.11 & 4.31 & 11.64 \\
\hline Verapamil & 22.65 & 6.67 & 18.01 \\
\hline Thymol & 23.50 & 1.39 & 3.75 \\
\hline Nonadecane (2,4 dimethyl 3hexanone) & 23.73 & 5.29 & 14.28 \\
\hline 2 Octen- 4one & 25.71 & 4.80 & 12.96 \\
\hline Heneicosana & 28.18 & 3.61 & 9.74 \\
\hline Dibutyl phenol & 28.94 & 1.72 & 4.64 \\
\hline Iso amyl salicylate & 30.21 & 5.22 & 14.09 \\
\hline Hexadecanoic acid & 31.32 & 2.87 & 5.59 \\
\hline 7-Trimethyl silyloxyl lavone & 32.55 & 2.79 & 7.53 \\
\hline Dihydroxycinnamic acid & 38.45 & 2.31 & 6.24 \\
\hline Verbenone & 40.33 & 5.71 & 15.42 \\
\hline 6 unknown & $\begin{array}{l}15.78,17.13 \\
17.74,19.47 \\
24.25,31.32\end{array}$ & 6.68 & 18.04 \\
\hline
\end{tabular}

In conclusion, the volatile oils of stevia leaves, licorice and chicory root have a characteristic flavour, due to the presence of many components with strong sensory properties at a low threshold, such as ethyl cinnamate and thus could be suitable for using as flavouring agent in food industry. These volatile oils can also be used as an antioxidant in foods, as well as anti-flammatory.
Finally, it is recommended that further studies are needed to measure the activity of such volatile compounds and their constituents in food products. In addition, safety studies have to be carried out as well.

\section{DEDICATETION}

Authors Mona, I. Massoud and Zeitoun, M.A. dedicate the present research paper to soul of Prof. Moussa, M.M. who suggested the problem of the work. 


\section{REFERENCES}

Aksit, S., Caglayan, S., Cukan, R. \& Yaprak, I. 1998. Carob bean juice: A powerfull adjunct to oral rehydration solution treatment in diarrhea. Paediatr Perinat Epidemiol., 12: $176-81$.

Baek, H.H. \& Cadwallader, K. R.1998. Roasted chicory aroma evaluation by gas chromatography / mass spectrometry / olfactometry. J. Food Sci., 63:234-237.

Bielenberg, J. 2001. Isoflavonoids from root as as mediators of anti-inflammatory and anti-allergic effects. Zeitschrift für Phytotherapie., 22: 289-293.

Buckenhuskers, H.J. \& Omran, H.T. 1997. Stevia rebaudiana Bertoni and stevioside. Sugar \& S. Subst. in Fd. Proc. \& Nutr. Ismailia, Oct. 157-178.

Burt, S. 2004. Essential oils: Their antibacterial properties and potential applications in foods $-\mathrm{A}$ review. Inter. J. Food Microbiol. , 94, 223-253.

Camacho, M.M., Martinez-Navarrete, N. \& Chiralt, A. 1996. Functional properties of Locust Bean Gum: A review. Proceedings of the 3rd International Carob Symposium, Cabanas-Tavira, Portugal; Facultade de Ciencias de Lisboa. Lisboa, Portugal, p 32.

Cantalejo, M.J. 1997. Effects of roasting temperature on the aroma components of carob (ceratonia siliqua L.). J. Agric. Food Chem., $45: 1345-1350$.

Cardoso, J.H., Mato-Brito, B.G., Junior, J.E., Viana-Cardoso, K.V., Sampaio-Freitas, R.O., Brasil, A.N \& Albuquerque, A.A. 2004. Effects of estragole on the compound action potential of the rat sciatic nerve. Braz J Med Biol Res 37: 1193-1198.

Dasgupta, A. \& Humphrey, P.E. (1998). Gas chromatographic-mass spectrometric identification and quantitation of benzyl alcohol in serum after derivatization with perfluorooctanoyl chloride: A new derivative. J. Chromatogr B Biomed Sci Appl. , 24: 299-303

Geuns, J.M.C.2003. Stevioside. Phytochemistry, 64: 913-921.

Hazra, B., Sarkar, R., Bhattacharyya, S. \& Roy, P. 2002. Tumor inhibitory activity of chicory root extract against Ehrlich ascites carcinoma in mice. Fitoterapia., 73: 730-733.

Jeppesen, P.B., Gregersen, S., Poulsen, C.R. \& Hermansen, K. 2000. Stevioside acts directly on pancreatic beta cells to secrete insulin: Actions independent of cyclic adenosine monophosphate and adenosine triphosphate-sensitive $\mathrm{K}^{+}$Chennel activity. Metabolism., 49: 208-214.
Jiang, Y., Lu, H.T. \& Chen, F. 2004. Preparative purification of glycyrrhizin extracted from the root of liquorice using high-speed counter chromatography. J. Chromatogr. A, 1033: $184-186$.

Juglal, S., Govinden, R. \& Odhav, B. 2002. Spice oils for the control of co-occurring mycotoxin-producing fungi. J. of Food Protect., 65: 683-687.

Kameoka, H. \& Nakai, K. K. 1987. Components of essential oil from the root of Glycyrrhbiza glabra. Ag. Chem. Soc. Japan, 61: 1119-1121.

Karpouhtsis, L., Pardali, E., Feggou, E.; Kokkini, S., Scouras, Z.G. \& Mavragani-Tsipidou, P. (1998). Insecticidal and genotoxic activities of oregano essential oils. J. Agric. Food Chem., 46: 1111-1115.

Katayoun, M.S., Madjid, S. \& Bita, S. 2003. Comparison of antioxidant of extract from roots of (Glycyrrhiza glabra L.) to commercial antioxidants in 2-hydroquinone cream. J.Cosme. Sci., 54: 551-558.

Kinghorn, A.D. 2002. Stevia the Gens Stevia. Overview. In: Kinghorn, A.D. (ed) Medical and Aromatic Planta-Industrial Profiles. Vol.19 Taylor and Francis. London and NY pp1-17.

Luper, S. 1999. A review of plants used in the treatment of liver disease: part two. [Review]. Altern Med. Rev., 4: 178-188.

Macleod, G. \& Forcen, M. 1992. Analysis of volatile components derived from the carob bean Ceratonia siliqua. Phytochemistry, 31: 3113-3119.

Marakis,S. G. 1992. Sucrose syrup from carob pod. Biotechnol. Lett. ,14: 1075-1080.

Mari, M., Bertolini, P. \& Pratella, G.C. 2003. Non-conventional methods for the control of post-harvest pear diseases. J. Appl. Microbiol., 94: 691-766.

Martelli, A., Frattini, C. \& Chialva, F. 1985. Unusual essential oils with aromatic properties. 1. Volatile components of Stevia rebaudiana Bertoni. Flavour and Fragrance J., 1: 3-7.

Michael, D. 2003. What is (Glycyrrhiza glabra), glycyrrhiza. C.F. http//www.mdidea.com/ products/new 011.htm.

Nychas, G.J.E. 1995. Natural antimicrobials from plants .In: Gould, G.W. (ed) New Methods of Food Preservation. Blackie Acadenic and Professiona, London, pp. 58-89.

Pasquel, A., Meireles, M. A. A., Marques, M. O. M\& Petenate, A.J. 2000. Extraction of stevia glycosides with $\mathrm{CO}_{2}+$ water, $\mathrm{CO}_{2}$, ethanol and $\mathrm{CO}_{2}$ +water+ethanol. Braz. J. Chem. Eng. ,17. C.F. http://www.scielo.br/site-usage/reports. 
Pauli, A. \& Schicher, H. 2004. Scpecific selection of essential oil compounds for treatment of children infection diseases .Pharm.,1:1-30.

Pessoa, L.M., Morais, S. M., Bevilaqua, C.M.L. \& Luciano, H.S. 2002. Anthelmintic activity of essential oil of Ocimum gratissimum Linn and eugenol against Haemonchus contortus. Veterinary Parasitol., 109: 59-63.

Piet, D. P. 1996. Transannular cyclisation reactions of the germacrane system mediated by enzymes from Chichorium inhybus. C.F. http//:www. Library. war. nl./wda/.

Roman, L U.,Mora, Y. \&Hernandez, J. D. 1990. Stevia serrata, a source of chamazulene. Fitoterapia., 61:84

Roukas, T. 1994. Continuous ethanol production from carob pod extract by immobilized Saccharomyces cerevisiae in a packed- bed reactor. J. Chem. Technol. Biotechnol., 59: 387-393.

Sannai, A.,Fujimon,T.\& Kato,K. 1982. Studies on flavor components of roasted chicory root .Agric.Biol.Chem.,46: 429-433.

Tanaka, Y., Kikuzaki, H.S., Fukuda, S. \& Nakatani, N. 2001. Antibacterial compounds of licorice against upper airway respiratory tract pathogens. J. Nutr. Sci. and Vitam., 47: 270-273.

Tamir, S., Eizenberg, M., Somjen, D., Sarit, I. \& Vaya, J. 2001. Estrogen-like activity of glabrene and other constituents isolated from root. J. of Steroids Biochem. and Mol. Biol., 78: 291-298.

Tsanava, V.P., Sardzhveladze, G.P. \& Kharebava, L.G. 1991. Effect of technological procedures on the composition of volatile substances in Stevia rebaudiana, Subtrop. Kul't, 3, 64.CF: Chemical Abstracts 116: $82387 \mathrm{~g}$.

Tucker, A.O. \& Maciarello, M.J. 1999. Volatile leaf oil of the "Verbena" [Lippia alba (Mill) N.E. Brown ex Brown ex Britton and P. Wils. Var. Carterae Moldenke] from the North American herb trade. J. Essential Oil Res., 11: 314-316.

Van de Braak, S.A.J. \& Leijten, G.C.J. 1999. Essential Oils and Oleoresins: A survey in the Netherlands and other Major Markets in the European Union. CBI, Centre for Promotion of Imports from Developing Countries, Rotterdam, 1160.

\section{التعرف على المرَّبَاتِ الطيارة المستخلصة من بَعض النباتاتِ الطبيةِ

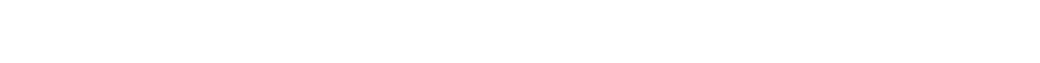

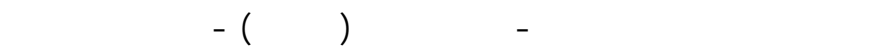

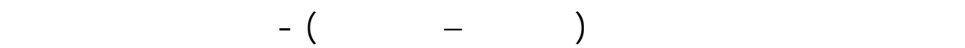

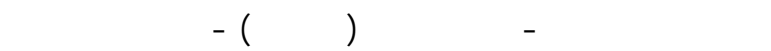

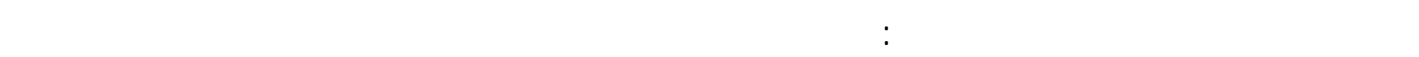

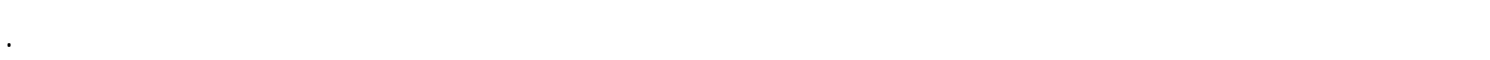

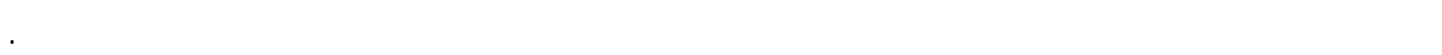

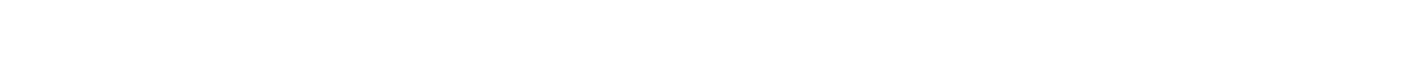

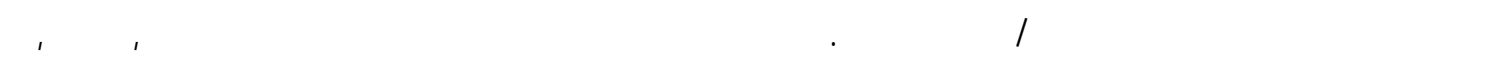

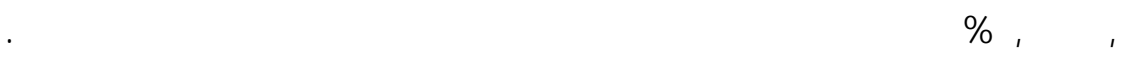
وأوضحت الدرلسة النتائج التالية:

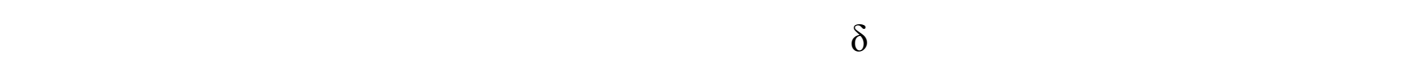

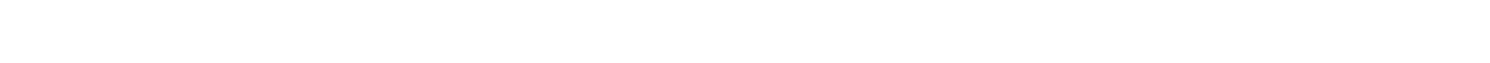
والبنزالدهيد والينالول.

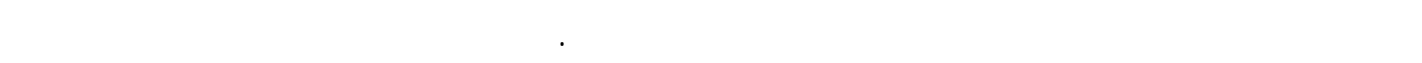

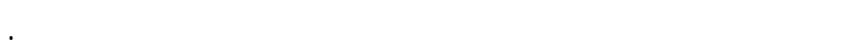

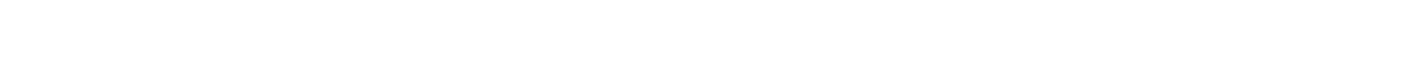
مكسبه للنكهة في مجل الصناعلت الغذائية. 